\title{
A PRÁTICA DE CONTESTAÇÃO NO PROCESSO CIVILL_²
}

\section{THE PRACTICE OF THE DEFENSE ON THE CIVIL PROCESS}

\section{Guilherme César Pinheiro}

Doutor e Mestre em Direito Processual pelo Programa de Pós-graduação em Direito (PPGD) da Pontifícia Universidade Católica de Minas Gerais - PUCMINAS. Coordenador do Núcleo de Práticas Jurídicas e Professor de Direito Processual Civil e Prática Jurídica da Universidade do Estado de Minas Gerais (UEMG), unidade Diamantina/MG. Advogado atuante. E-mail: guilhermepinheiro.adv@ hotmail.com.

RESUMO: O artigo tem como objetivo geral abordar aspectos práticos da contestação no processo civil, mediante análise sistemática do CPC e da técnica processual, a partir do marco teórico de compreensão do processo constitucional como metodologia de garantia de Direito Fundamentais. Especificamente, visa a enfatizar a importância da técnica processual para formulação de resistência e requerimentos, bem como para arguir questões preliminares e de mérito na defesa do réu, a fim de que esta seja ampla e eficaz.

PALAVRAS-CHAVE: Defesa do réu; contestação; técnica processual; prática jurídica.

\begin{abstract}
The article aims, generally, to approach practical aspects of the defense on the civil process, through systematic analysis of the CPC and of the procedural technique, from to theoretical framework of understanding constitutional process as methodology of warranty of Fundamental Rights. Specifically, aims to emphasize the importance of the

\footnotetext{
${ }^{1}$ Artigo recebido em 25/10/2020 e aprovado em 21/04/2021.

2 Artigo escrito especialmente para os alunos de Prática Jurídica do Curso de Bacharelado em Direito da Universidade do Estado de Minas Gerais (UEMG), unidade Diamantina, durante o período de isolamento social ocasionado pela pandemia da COVID-19.
} 
procedural technique to formulation of the resistance and requirement, as well as to argue preliminary and merits questions in the defendant's defense, in order to that it is ample and effective.

KEYWORDS: Defendant's defense; defense; procedural technique; legal practice.

\section{INTRODUÇÃ̃O}

Contestação é a forma técnico-jurídica pela qual o réu, no processo de conhecimento, responde e resiste à pretensão manifestada pelo autor na petição inicial. É a resposta que viabiliza defesa de maneira mais enérgica, completa e eficaz, porque o possibilita insurgir contra o processo instaurado, mediante arguição de preliminares (art. 337 CPC), e contra o mérito, impugnando a causa de pedir e os pedidos do autor, de modo direito e/ou indireto ${ }^{3}$. Nas palavras de Humberto Theodoro Junior, "contestação, portanto, é instrumento processual utilizado pelo réu para opor-se, formal ou materialmente, à pretensão deduzida em juízo pelo autor" 4 . Para Rosemiro Pereira Leal, em síntese, "contestação é pretensão resistida"5.

É oportuno, também, lembrar que na contestação é possível provocar a intervenção de terceiros, notadamente a denunciação da lide e o chamamento ao processo.

Vê-se que o ato de oferecer contestação é formal e eminentemente técnico, de sorte a exigir intervenção de advogado regularmente inscrito no quadro da Ordem dos Advogados do Brasil - capacidade postulatória - e tecnicamente qualificado (direito à ampla defesa - artigos $5^{\circ}$, inciso LV, e 133 da Constituição brasileira). Para ser eficazmente ampla a defesa tem de garantir posicionamento estratégico e crítico-

\footnotetext{
${ }^{3}$ BRÊTAS, Ronaldo de Carvalho Dias. Fundamentos e inovações do Código de Processo Civil. Belo Horizonte, D'Plácido, 2020, p. 118.

${ }^{4}$ THEODORO JR., Humberto. Curso de Direito Processual Civil - Volume I. 56 Edição. Rio de Janeiro: Forense. 2015, p. 789.

${ }^{5}$ LEAL, Rosemiro Pereira. Teoria geral do processo: primeiros estudos. $8^{\text {a }}$. Ed. Belo Horizonte: Forense, 2009, p. 310-311.
} 
argumentativo frente à pretensão e à resistência apresentada pela outra parte e até mesmo em relação aos pronunciamentos decisórios lavrados no processo ${ }^{6}$.

Por essas breves considerações, fica claro por quê a sua prática costuma ser assunto tormentoso aos estudantes de graduação e até mesmo aos advogados em início de carreira ou com pouca vivência forense. Soma-se a isso o fato de que os manuais de Direito Processual Civil, quando abordam as formas de respostas do réu, se ocupam (quase) exclusivamente de assuntos teóricos, olvidando-se dos aspectos práticos e técnicos da contestação. Os manuais de prática, por seu turno, não suprem tal deficiência, uma vez que, a grande maioria, limitam-se à apresentação de "modelos" de peças, os quais muito pouco (ou quase nada) contribuem para o processo de ensino e aprendizagem jurídica.

Nessa perspectiva, o texto objetiva expor o tema "prática de elaboração de contestação no processo civil". Assim o faz, mediante análise sistemática do CPC e da técnica processual, a partir da compreensão de processo constitucional como metodologia de garantia de direitos fundamentais ${ }^{7}$.

Nesse sentido, o artigo é divido em 5 tópicos. O primeiro aborda o prazo da contestação e as regras de seu cômputo. O segundo discorre acerca da necessidade e da importância de impugnação específica dos fatos articulados na petição inicial, bem como sobre a ideia de concentração ou eventualidade da defesa. $\mathrm{O}$ terceiro analisa as questões preliminares, destacando a importância de provocar o juiz a acolhê-las ao final da contestação, mediante postulação no sentido de que as consequências jurídicas normatizadas no CPC sejam aplicadas. O quarto dispõe sobre as defesas de mérito. Por fim, o quinto e último ressalta a importância de formulação de pedidos e requerimentos, de modo a delimitar a resistência do réu, formatando-se, por completo, objeto do processo.

\footnotetext{
${ }^{6}$ BAHIA, Alexandre; NUNES, Dierle; QUINAUD PEDRON, Flávio. Teoria Geral do Processo: com comentários sobre a virada tecnológica no direito processual. Salvador: JusPodivm. 2020, p. 360.

${ }^{7}$ BARACHO, José Alfredo de Oliveira. Direito processual constitucional: aspectos contemporâneos. Belo Horizonte: Fórum, 2008; BARACHO, José Alfredo de Oliveira Teoria geral do processo constitucional. Revista da Faculdade Mineira de Direito, Belo Horizonte, v. 2, n. 3 e 4, p. 89-154, $1^{\circ}$ e $2^{\circ}$ sem. 1999. BRÊTAS C. DIAS, Ronaldo. Processo Constitucional e Estado Democrático de Direito. $4^{\mathrm{a}}$ Ed. Belo Horizonte: Del Rey, 2018; BRÊTAS, Ronaldo de Carvalho Dias. Fundamentos e inovações do Código de Processo Civil. Belo Horizonte, D’Plácido, 2020.
} 


\section{PRAZO E AS REGRAS DE SEU CÔMPUTO}

O prazo para oferecimento de contestação no procedimento comum do processo de conhecimento é de 15 (quinze) dias úteis, contados de três diferentes termos iniciais, os quais têm como referência a realização ou não da audiência de conciliação ou mediação, normatizada no art. 334 do CPC.

Primeira situação: caso ocorra a referida audiência, sem que se obtenha êxito na solução consensual do litígio ( $=$ transação ${ }^{8}$ ), o termo inicial da quinzena para contestar será a data audiência ou de sua última sessão, se forem necessárias mais de uma (art. 335, I, CPC).

Por outro lado, há outas duas situações nas quais a audiência para tentativa de solução consensual do litígio não ocorre.

Segunda situação: quando autor e réu, expressamente, manifestarem-se desinteressados em transacionar. Para tanto, o autor deve manifestar seu desinteresse na petição inicial (art. 319, IV, CPC), de sorte que o seu silêncio é interpretado como interesse em participar da audiência em questão ${ }^{9}$. O réu, por sua vez, deverá fazê-lo por petição a ser protocolada com $10(\mathrm{dez})$ dias de antecedência, contados da audiência, requerendo o seu cancelamento. Em tais situações, o termo inicial dos 15 dias para contestar é a data do protocolo da petição em que o réu manifestou seu desinteresse na solução consensual e requereu o cancelamento da audiência que havia sido designada.

\footnotetext{
${ }^{8}$ É oportuno observar a distinção, muitas vezes esquecidas no dia a dia, entre mediação e conciliação, que são técnicas consensuais de solução de litígios, e o seu resultado desejado, qual seja: a transação, que se caracteriza por concessões mútuas entre os interessados. As técnicas de mediação e conciliação são utilizadas com a finalidade de possibilitar, primeiro, o restabelecimento do diálogo entre partes diretamente interessadas, para que eventualmente, a partir do livre exercício da autonomia privada, solucionem consensualmente o litígio. Portanto, mediação e conciliação não se confundem com seu resultado esperado: a transação, popularmente conhecido como "fazer acordo" (PINHEIRO, Guilherme César. A audiência de conciliação e mediação no sistema processual civil. Revista Eletrônica de Direito Processual - REDP. Rio de Janeiro. Ano 12. Volume 19. Número 3: setembro a dezembro de 2018, p. 334-336; BARROS, Flaviane de Magalhães; CARVALHO, Marius Fernando Cunha de; GUIMARÃES, Natália Chernicharo. O consenso compreendido a partir do paradigma do Estado Democrático de Direito. Revista de Informação Legislativa, Brasília, v. 168, nº dez, 2005, p. 147-153.

${ }^{9}$ PINHEIRO, Guilherme César. O Novo Código de Processo Civil e as alterações não explícitas sobre a petição inicial. Revista de Processo. Vol. 258. Ano 41. São Paulo: Editora Revista dos Tribunais, ago. 2016, p. 99; PINHEIRO, Guilherme César; SOUSA, Lorena Ribeiro de Carvalho. A petição inicial e os seus requisitos no Novo Código de Processo Civil. REVISTA ESMAT, v. 10, n. 15, 30 ago. 2018, p. 98.
} 
Existindo litisconsórcio de réus, o desinteresse na realização da audiência dever ser manifestado por todos, hipótese na qual o prazo para resposta terá como marco inicial, para cada um deles, a data de apresentação de sua respectiva petição de cancelamento. Isso significa que se, por exemplo, o processo tiver três réus e cada um deles manifestar isoladamente desinteresse na realização de audiência de autocomposição em diferentes dias, a fluência do prazo para contestar terá início em datas separadas e fluirá de modo independente para cada um dos réus (art. 335, II, $\S 1^{\circ}, \mathrm{CPC}$ ).

Terceira situação: quando não se admitir a autocomposição, circunstância em que o réu é citado e intimado diretamente para oferecer resposta (art. 335, III, CPC). Se assim for, o início da contagem do prazo para contestar dependerá da forma em que ocorrer a citação do réu.

A partir da Lei 14.195/2021, a citação deve ser feita preferencialmente por meio eletrônico e encaminhadas aos endereços eletrônicos indicados pelo citando no banco de dados do Poder Judiciário, conforme regulamento do Conselho Nacional de Justiça. Para tanto, as pessoas jurídicas de direito público e privado têm o dever de manter cadastro nos sistemas de processo em autos eletrônicos, justamente para receber citações e intimações (art. 246 CPC). Nesse caso, o termo inicial da quinzena para contestar será o quinto dia útil seguinte à confirmação do recebimento da citação realizada por meio eletrônico - art. 231, IX, CPC -, que será acompanhada de orientações para confirmação de recebimento e de código identificador, permitindo-se a sua identificação na página eletrônica do órgão judicial citante (art. $\left.246 \S 4^{\circ} \mathrm{CPC}\right)^{10}$.

Se o réu for citado por via postal, será a data de juntada aos autos do aviso de recebimento (art. 231, I, CPC); caso seja citado por oficial de justiça, o termo inicial será a data de juntada aos autos do mandado cumprido (art. 231, II, CPC). Nos casos de citação

\footnotetext{
${ }^{10}$ Se o citando não confirmar o recebimento da citação eletrônica, em até 3 (três) dias úteis, contados da data do recebimento da mensagem eletrônica, a citação deverá ser realizada pelos meios tradicionais: pelo correio, por oficial de justiça, pelo escrivão ou chefe de secretaria, por edital. Quando isso acontecer, o citando deverá, na primeira oportunidade de falar nos autos, apresentar justa causa para a ausência de confirmação do recebimento da citação enviada eletronicamente, porque se considerar-se-á ato atentatório à dignidade da justiça, passível de multa de até 5\% (cinco por cento) do valor da causa, deixar de confirmar no prazo legal, sem justa causa, o recebimento da citação recebida por meio eletrônico (art. $246 \S^{\circ}$ - A, $\S 1^{\circ}-\mathrm{B}$ e $\left.\S 1^{\circ}-\mathrm{C}, \mathrm{CPC}\right)$.
} 
por carta precatória, o início da quinzena é a data da juntada do comunicado pelo qual o juízo deprecado informa ao juízo deprecante que a citação se realizou (art. 231, VI, CPC).

Nessas três situações, o prazo para contestar se inicia da juntada do comprovante de citação aos autos e, se houver mais de um réu, a fluência do prazo quinzenal corresponde à última das datas em que ocorreu a juntada do comprovante de citação nos autos. Percebe-se que esta é importante para marcar o momento em que se verificou a litispendência, constituiu o devedor em mora e tornou litigiosa a relação jurídica discutida no processo.

Ocorrendo a citação por ato do escrivão ou do chefe da secretaria, o prazo de 15 dias tem como marco inicial a data da ocorrência da citação (art. 231, III, CPC). Se ocorrer por meio eletrônico, o dia útil seguinte à consulta ao seu teor é o termo inicial para responder. Por fim, nos casos de citação por edital, o termo inicial será o dia útil seguinte ao fim da dilação assinada pelo juiz (art. 231, IV, CPC).

Embora existam diferentes marcos iniciais de contagem do prazo em questão, são uniformes suas as regras de cômputo. O dia de início é sempre excluído e incluído o de vencimento, que é a data limite para o oferecimento da contestação. Conta-se apenas os dias úteis, ficando o prazo suspenso nos dias que não houver expediente forense. Os dias do começo e do vencimento do prazo são protraídos para o primeiro dia útil subsequente, se coincidirem com dia em que o expediente forense for encerrado antes ou iniciado depois do horário normal ou houver indisponibilidade da comunicação eletrônica (artigos 219 e 224 CPC).

\section{IMPUGNAÇÃO ESPECÍFICA DOS FATOS E A CONCENTRAÇÃO NA CONTESTAÇÃO}

Há duas regras básicas que orientam à estratégia técnica de feitura de contestações: 1) impugnação específica dos fatos; 2) eventualidade ou concentração.

A regra ônus da impugnação específica dos fatos é normatizada pelo artigo 341 do CPC e dispõe sobre a necessidade de o réu manifestar-se contrariamente aos fatos constitutivos do direito do autor e articulados na petição inicial (= "pontos"), de modo a gerar controvérsia a respeito, transformando-os em "questões" (= pontos controvertidos). 
Tal é válido também em relação aos documentos apresentados pelo autor como prova dos fatos constitutivos de seu direito, sendo recomendável impugnar especificadamente documento por documento, negando-lhe pertinente e validade jurídica e probatória. Se o réu assim não proceder, serão presumidos verdadeiros os fatos articulados pelo autor, de tal sorte a dispensar a necessidade de provas (art. 374, inciso III, CPC).

Vê-se o quão importante é a regra da necessidade de impugnação específica dos fatos e dos documentos que instruíram à petição inicial. É que o simples fato de o réu oferecer defesa, com negativa especificada (e não genérica) de ocorrência dos fatos articulados na narrativa da causa de pedir, suscitará seja observada a regra do art. 373, inciso I, do CPC, como critério de apreciação do mérito do processo. Logo, será do autor o ônus de provar os fatos constitutivos de seu direito, visto que milita no processo civil presunção de improcedência dos pedidos do autor ${ }^{11}$. Isso evidencia a relevância de oferecimento de contestação, ainda que exclusivamente para estabelecer controvérsia fática sobre os pontos da narrativa da causa de pedir.

A outra regra básica de orientação à feitura de contestações é a eventualidade ou concentração da defesa, que impõe ao réu a obrigatoriedade de apresentar, à exaustão, todas as questões fático-jurídicas relativas à sua defesa, sejam elas processuais ou de mérito (art. 336 CPC). Tal ocorre porque, depois de oferecida contestação, somente é permitido ao réu suscitar questões de ordem pública; pertinentes a direito ou a fato superveniente; ou que o juiz possa conhecê-las de ofício (art. 342 CPC). Por isso, não ser lícito ao réu apresentar defesa de modo gradual e sucessivo. Não se admite "guardar cartas mangas" para apresentá-las quando for pertinente ou em casos de não acolhimento de outras questões. A defesa tem de ser oferecida de uma só vez e por completo, abordando todos os fatos e questões pertinentes, mesmo que contenham argumentos e questões excludentes entre $\mathrm{si}^{12}$. O réu pode, por exemplo, em processo no qual o autor pleiteia a sua condenação ao pagamento de $\mathrm{R} \$ 100.000,00$ em decorrência de um contrato

${ }^{11}$ COSTA, Eduardo José da Fonseca. Presunção de inocência civil: algumas reflexões no contexto brasileiro. Revista Brasileira de Direito Processual - RBDPro, Belo Horizonte, ano 25, n. 100, p. 129-144, out./dez. 2017.

${ }^{12}$ DIDIER JR., Fredie. Curso de Direito Processual Civil: introdução ao direito processual civil parte geral e processo de conhecimento. Vol. 1. 17ª Edição. Salvador: Editora JusPodivm, 2015, p. 638-640; BRÊTAS, Ronaldo de Carvalho Dias. Fundamentos e inovações do Código de Processo Civil. Belo Horizonte, D’Plácido, 2020, p. 120. 
de mútuo, defender-se dizendo que: 1) "o referido contrato nunca existiu"; 2) "a pretensão do autor está extinta pela prescrição"; 3) "o autor também deve o réu, o que autoriza a compreensão dos débitos".

\section{ESTRUTURA DA CONTESTAÇÃO}

A contestação é formal, porque dividida, estruturalmente, em duas partes: 1) preliminares; 2) mérito, nesta ordem (art. 337 CPC).

\subsection{Questões preliminares}

Os trezes incisos do art. 337 arrolam as preliminares que podem ser arguidas pelo réu em sua defesa. Com exceção da incompetência relativa (inciso II) e da convenção de arbitragem (inciso X), as preliminares ao mérito são questões processuais de ordem pública, motivo pelo qual podem ser conhecidas de ofício pelo magistrado. Entretanto, o advogado diligente é quem deve tomar a iniciativa de argui-las sempre que cabíveis.

A melhor técnica processual recomenda sejas as preliminares classificadas em três grupos: 1) dilatórias; 2) peremptórias; 3) dilatórias, mas potencialmente peremptórias. Essa classificação toma por parâmetro as consequências processuais previstas para cada grupo, em caso de seu acolhimento pelo juiz ${ }^{13}$, de tal sorte a orientar o pedido a ser formulado pelo réu, ao final de sua contestação. Daí a importância técnica e prática em diferenciar e agrupar as questões preliminares.

Preliminares peremptórias são aquelas questões processuais que, se acolhidas ou declaradas de ofício pelo juiz, implicam, inevitavelmente, extinção do processo sem apreciação do mérito, haja vista serem compreendidas como vícios insanáveis, não suscetíveis de posterior convalidação. A consequência é uma só: extinção do processo sem apreciação do mérito, não havendo ato posterior que possa corrigir o vício constatado.

\footnotetext{
${ }^{13}$ NEVES, Daniel Amorim Assumpção. Manual de Direito Processual Civil - Volume único. $8^{\text {a }}$ Edição. Salvador: JusPodivm, 2016, p. 579-580.
} 
Preliminares dilatórias são aquelas questões processuais que, se acolhidas declaradas de ofício pelo juiz, não implicam extinção do processo sem resolução do mérito. Apenas exigem a prática de atos subsequentes, a fim de que o vício ou erro processual a que se refere à questão preliminar seja saneado, corrigido. São questões que aumentam o número de atos processuais a serem praticados até a apreciação do mérito ${ }^{14}$. Por essa razão, recebem o nome "dilatórias", pois relativas ao que se "aumenta", se "dilata".

É de extrema importância salientar que existem preliminares que são inicialmente dilatórias, mas que podem acarretar a extinção do processo sem apreciação do mérito, se o autor não cumprir a diligência necessária à correção do vício processual (art. 485, incisos III e IV, CPC). Tal situação processual é designada de contumácia (= desídia procedimental por parte do autor, que deixa de praticar ato que lhe incumbe no curso do processo) $)^{15}$.

Essas considerações introdutórias são essenciais para adequada compreensão dos aspectos práticos e técnicos da apresentação de contestação no processo civil.

\subsubsection{Inexistência ou nulidade de citação}

A citação é ato processual relevante, porque informa ao réu a respeito do ajuizamento de pretensão em seu desfavor e lhe oportuniza resposta e participação no processo. É, portanto, indispensável sua ocorrência e a observância da forma legal estabelecida. Assim, se a citação for inexistente ou ocorrer em desconformidade à legislação processual, os atos que lhe são subsequentes tornam-se suscetíveis à declaração de nulidade, quando ficar demonstrado prejuízo ao réu.

Nessa perspectiva, percebe-se que a preliminar em questão é dilatória, por não implicar extinção do processo sem apreciação do mérito. Até porque o comparecimento espontâneo do réu supre a citação. Seu acolhimento tem como consequência a nulidade

\footnotetext{
${ }^{14}$ THEODORO JR., Humberto. Curso de Direito Processual Civil - Volume I. 56 ${ }^{\text {a }}$ Edição. Rio de Janeiro: Forense. 2015, p. 785.

${ }^{15}$ BRÊTAS, Ronaldo de Carvalho Dias. Fundamentos e inovaçães do Código de Processo Civil. Belo Horizonte, D'Plácido, 2020, p. 124.
} 
de atos subsequentes à citação não realizada ou realizada desconforme à ordem jurídica. Logo, quando o réu arguir inexistência ou nulidade de citação, deverá, ao final, manifestar resistência no sentido de que a preliminar seja acolhida e declarada a nulidade do processo, especificamente de todos os atos subsequentes à citação, dos quais a participação do réu foi alijada.

\subsubsection{Incompetência absoluta ou relativa do juízo}

Segundo o conteúdo normativo dos artigos 64, caput, 337, inciso II, ambos do CPC a incompetência, absoluta ou relativa, é arguível na contestação. É interessante anotar que a incompetência absoluta pode ser declarada de ofício pelo juiz, sendo-lhe, porém, vedado conhecer de ofício da incompetência relativa, que será prorrogada, se não arguida pelo réu em preliminar de contestação (artigos 64 e 65 CPC).

De todo modo, a incompetência absoluta ou relativa são questões preliminares dilatórias e têm como consequência jurídica a declinação da competência, remetendo-se os autos ao juízo competente (art. $64, \S 3^{\circ}, \mathrm{CPC}$ ). Não geram, pois, a extinção do processo sem apreciação do mérito.

O que merece destaque é a faculdade de o réu fazer o protocolo no foro de seu domicílio, quando for arguir incompetência relativa ou absoluta. Se assim for feito, a contestação será submetida a livre distribuição ou, se o réu houver sido citado por meio de carta precatória, juntada aos seus autos, seguindo-se a sua imediata remessa para o juízo da causa.

O propósito dessa disposição normativa é facilitar e permitir que o réu ofereça contestação no foro do seu próprio domicílio, que seria o do juízo competente. Isso para que a audiência de conciliação ou mediação designada seja suspensa até que se aprecie a questão suscitada pelo réu. A intenção, ao final, é que o réu não seja obrigado a comparecer à audiência de conciliação ou mediação perante juízo incompetente.

Porém, a novidade não é boa, se compreendida de maneira sistemática. É que o procedimento comum do processo de conhecimento dispõe que a contestação será oferecida, como regra, no prazo de 15 dias após a audiência de conciliação ou mediação. Assim, não parece lógico exigir do réu o oferecimento de contestação antes da realização 
da referida audiência e com a finalidade de suspender sua realização. Lembrando que a contestação deve ser apresentada por inteiro, de uma vez só, em razão da regra da eventualidade (artigos 336 e 342 do CPC).

\subsubsection{Incorreção ao valor da causa}

No regime processual anterior - CPC/1973 - a incorreção ao valor da causa era suscitada mediante incidente processual, nominado de "impugnação ao valor da causa". O CPC em vigor alterou a forma de arguir tal vício processual e estabeleceu seja tal questão suscitada em preliminar de contestação, sob pena de preclusão (art. 293 CPC).

O acolhimento da preliminar de impugnação ao valor da causa poderá refletir na necessidade de recolhimento (ou complementação) das custas processuais correspondentes (art. 292, § $3^{\circ}$, CPC), bem como na condenação ao pagamento de honorários de sucumbência. $\mathrm{O}$ valor da causa é parâmetro para o estabelecimento das custas processuais iniciais a serem recolhidas, quando do ajuizamento da ação, assim como para fixação de valores a serem pagos pela parte sucumbente, a título de honorários advocatícios ${ }^{16}$. Com isso, se o autor tiver indicado valor da causa em desconformidade com o art. 292 do CPC, de tal maneira a implicar recolhimento de custas iniciais inferior ao devido, deverá ser determinada complementação do valor restante, sob pena de extinção do processo sem apreciação do mérito.

Percebe-se que a preliminar de incorreção ao valor da causa é inicialmente dilatória com possibilidade de se tornar peremptória, caso o autor não cumpra a diligência necessária ao saneamento do vício processual em questão. Logo, a arguição de incorreção ao valor da causa deve vir acompanhada de manifestação de resistência no sentido de que o valor da causa seja corrigido e autor intimado a recolher (ou complementar) às custas correspondentes, se for o caso (art. 293 CPC), sob a consequência de extinção do processo sem apreciação do mérito (art. 485, III e IV, CPC).

\footnotetext{
${ }^{16}$ BRÊTAS, Ronaldo de Carvalho Dias. Fundamentos e inovaçães do Código de Processo Civil. Belo Horizonte, D'Plácido, 2020, p. 123.
} 


\subsubsection{Inépcia da petição inicial}

As situações de inépcia da petição inicial são normatizadas no art. 330, caput e $\S$ $1^{\circ}$, do CPC e se referem a erros crassos em relativos à causa de pedir, ao pedido(s) e à relação entre causa de pedir e pedido. A petição inicial é inepta quando: a) lhe faltar pedido ou causa de pedir; $b$ ) o pedido for indeterminado, ressalvadas as hipóteses em que se permite pedido genérico; $c$ ) da narração dos fatos não decorrer logicamente a conclusão; $d$ ) contiver pedidos incompatíveis entre si.

Conforme visto, a inépcia da petição inicial decorre de vícios processuais graves, que, ao final, prejudicam a própria defesa do réu. São vícios que não se limitam apenas aos requisitos formais da petição inicial e aos documentos indispensáveis à propositura da ação. A petição inicial é inepta quando seus vícios dizem respeito à possibilidade de compreensão clara da pretensão manifestada pelo autor ${ }^{17}$.

Portanto, a preliminar de "inépcia da petição inicial" é dilatória, mas pode tornarse peremptória, caso o autor não emende a petição inicial, nos termos do art. 321 do CPC. Assim sendo, o réu deverá argui-la e manifestar resistência no sentido de acolhimento da preliminar, a fim de que o autor seja intimado para emendar a petição inicial no prazo de 15 dias.

\subsubsection{Litispendência, perempção e coisa julgada}

São três questões preliminares diferentes, mas que merecem tratamento conjunto, ante as suas semelhanças. As três questões exigem para sua configuração que haja identidade de partes, causas de pedir e pedido. São os elementos configurativos do processo (ou elementos da ação). Assim, um processo (ou uma ação) é igual é ao outro (à outra) quando há identidade de partes, causa de pedir e pedido.

Há litispendência quando se repete processo que está em curso. Já coisa julgada ocorre quando se repete processo cuja pretensão foi apreciada por decisão passada em

17 SOARES, Carlos Henrique. Curso de Teoria Geral do Processo Civil. Belo Horizonte; Editora D’Plácido, 2019, p. 537. 
julgada. A perempção, por sua vez, é verificada em situações nas quais o processo é extinto por 3 vezes por contumácia, abandono processual.

Essas três questões preliminares são peremptórias e implicam extinção do processo sem apreciação do mérito. Logo, o réu deve manifestar resistência no sentido de que seja acolhida a questão arguida e, via de consequência, extinto o processo sem que seu mérito seja apreciado.

\subsubsection{Conexão e Continência}

Há conexão entre dois ou mais procedimentos quando lhes for comum pedido ou causa de pedir (art. $55 \mathrm{CPC}$ ). Clarifica-se que o texto do mencionado art., em sua literalidade, afirma que "Reputam-se conexas duas ou mais ações, quando Ihes for comum o objeto ou a causa de pedir". Com isso, relevante anotar que o "ou” empregado no texto é "conjuntivo", vale dizer, tem sentido de "elou". Logo, há conexão entre dois ou mais processos em caso de apenas um dos elementos (causa de pedir ou pedido) for idêntico, assim como na hipótese de ambos os serem.

Situação especial de conexão entre processos é a continência, que se verifica quando existir entre eles identidade de partes e causa de pedir, mas o pedido de um, por ser mais amplo, abranger o(s) do(s) outro(s) - art. 56 CPC. Necessário, pois, que o pedido de um seja mais amplo que do outro, de modo que este esteja contido naquele. Por isso é que se fala em processo ou ação continente (= aquele que tem o pedido mais amplo) e processo contido ou ação contida (= aquele(a) cujo(a) pedido encontra-se abrangido pelo processo ou ação continente).

Um exemplo pode ajudar na compreensão do tema. Imagine que Ricardo tenha instaurado procedimento especial de separação judicial em desfavor de Márcia, com petição inicial distribuída à $7^{a}$ Vara de Família da Comarca de Belo Horizonte, Minas Gerais. Ocorre que Márcia já havia instaurado procedimento especial de divórcio em desfavor de Ricardo, cuja petição inicial foi distribuída à $3^{a}$ Vara de Família da referida Comarca. Percebe-se que os processos são continentes, porque possuem idênticas partes - Ricardo e Márcia - e causa de pedir (casamento). Porém, o pedido de divórcio 
formulado por Márcia é mais abrangente que o pedido de separação judicial formulado Ricardo, que se encontra contido naquele (divórcio) $)^{18}$.

A conexão e a continência são situações processuais de modificação de competência relativa (art. 54 CPC) e sua consequência jurídica é a reunião dos processos perante o juízo prevento, a fim de que as pretensões e resistências neles formuladas sejam apreciadas conjuntamente, de modo a evitar decisões conflitantes. A exceção fica por conta das situações de continência, em que o processo com pedido mais abrangente tiver sido instaurado anteriormente. Se assim for, o processo no qual tiver sido formulado o pedido contido deverá ser extinto sem resolução do mérito (art. $57 \mathrm{CPC})^{19}$.

Portanto, conexão e continência são, geralmente, questões preliminares dilatórias, porque implicam reunião dos processos perante o juízo prevento. Seu acolhimento impõe seja os autos remetidos ao juízo competente, mediante declinação de competência, a exceção do disposto no artigo 57 do CPC.

Posto isso, quando o réu arguir conexão ou continência, deverá formular resistência no sentido de que os autos sejam remetidos ao juízo prevento, que é aquele em que primeiro ocorreu registro ou distribuição da petição inicial (art. $58 \mathrm{CPC}$ ). Somente será necessário pedir a extinção do processo sem apreciação do mérito, quando se estiver diante de continência e o procedimento do pedido mais abrangente for o do juízo prevento.

\subsubsection{Incapacidade da parte, defeito de representação ou falta de autorização}

Incapacidade da parte, defeito de representação ou falta de autorização são questões preliminares inicialmente dilatórias, cujos vícios são perfeitamente sanáveis, mas dependem do cumprimento de diligência do autor.

\footnotetext{
${ }^{18}$ RODRIGUES JR., Walsir Edson. O sistema dual facultativo de dissolução do casamento no projeto do novo Código de Processo Civil. In: FREIRE, Alexandre; DANTAS Bruno; NUNES, Dierle; DIDIER JR., Fredie; MEDINA, José Miguel Garcia; FUX Luiz; VOLPE CAMARGO, Luiz Henrique; OLIVEIRA, Pedro Miranda de. (Org.). Novas Tendências do Processo Civil. Salvador: JusPODIVM, 2014, v. 3, p. 791 806.

${ }^{19}$ NEVES, Daniel Amorim Assumpção. Manual de Direito Processual Civil - Volume único. $8^{a}$ Edição. Salvador: JusPodivm, 2016, p. 583.
} 
A incapacidade da parte diz respeito a requisito de validade do ato jurídico processual. No Direito brasileiro, capazes são as pessoas físicas maiores de 18 anos que não apresente qualquer das causas de incapacidade civil. Os menores e os reconhecidamente incapazes necessitam de representantes ou assistentes para que seus atos sejam válidos. Já as pessoas jurídicas são representadas ou presentadas em juízo, de acordo com o disposto no art. $75 \mathrm{CPC}^{20}$. Os exemplos mais corriqueiros de incapacidade da parte são os de menores que não estão devidamente representados ou assistidos por quem tenha tal incumbência (por exemplo, a mãe e/ou pai) e ausência de apresentação dos atos constitutivos da pessoa jurídica ${ }^{21}$.

O defeito de representação é caracterizado por vício na capacidade postulatória, que exige, como regra, ser a parte representada em juízo por advogado regulamente inscrito na Ordem dos Advogados do Brasil ${ }^{22}$. São os casos em que: (1) a procuração que outorgou poderes ao advogado não é anexada aos autos; (2) ou situações em que advogado não está regularmente habilitado na $\mathrm{OAB}$, em razão de suspensão ou exclusão de seus quadros; (3) não comprovação da autorização da pessoa que outorgou poderes, em nome da pessoa jurídica, para o advogado representá-la em juízo ${ }^{23}$.

A falta de autorização é verificada quando ausente o consentimento legalmente exigido de outra pessoa ao ajuizamento da ação, o que é excepcional na ordem jurídica brasileira $^{24}$. É o clássico exemplo do art. 73 do $\mathrm{CPC}$ : "O cônjuge necessitará do consentimento do outro para propor ação que verse sobre direito real imobiliário, salvo quando casados sob o regime de separação absoluta de bens".

Nesse sentido, conforme normatizado pelo art. 76 do CPC, verificada a incapacidade processual ou irregularidade de representação da parte, deverá o juiz intimar

\footnotetext{
${ }^{20}$ DIDIER JR., Fredie. Curso de Direito Processual Civil: introdução ao direito processual civil parte geral e processo de conhecimento. Vol. 1. 17 Edição. Salvador: Editora JusPodivm, 2015, p. 314-338; NEVES, Daniel Amorim Assumpção. Manual de Direito Processual Civil - Volume único. $8^{a}$ Edição. Salvador: JusPodivm, 2016, p. 107-109 e 586.

${ }^{21}$ SCARPINELlA BUENO, Cassio. Manual de Direito Processual Civil: volume único. $4^{\text {a }}$ Edição. São Paulo: Saraiva. 2018, p. 370.

${ }^{22}$ NEVES, Daniel Amorim Assumpção. Manual de Direito Processual Civil - Volume único. $8^{\mathrm{a}}$ Edição. Salvador: JusPodivm, 2016, p. 586.

${ }^{23}$ SOARES, Carlos Henrique. Curso de Teoria Geral do Processo Civil. Belo Horizonte; Editora D'Plácido, 2019, p. 431-432.

${ }^{24}$ NEVES, Daniel Amorim Assumpção. Manual de Direito Processual Civil - Volume único. $8^{\mathrm{a}}$ Edição. Salvador: JusPodivm, 2016, p. 586.
} 
o autor para proceder à regularização de sua representação processual, assinando prazo razoável para tanto. Logo, se o autor não cumprir sanar o vício processual, será o caso de extinção do processo sem apreciação do mérito (art. $76, \S 1^{\circ}$, inciso I, e 485, inciso IV, $\mathrm{CPC})^{25}$.

Dessa forma, quando o réu arguir incapacidade da parte, defeito de representação ou falta de autorização, deverá, ao final da contestação, manifestar resistência no sentido de que tal preliminar seja acolhida e, via de consequência, o autor intimado para sanar o vício processual referente à sua representação processual, sob a consequência de extinção do processo sem apreciação do mérito, nos termos dos artigos $76, \S 1^{\circ}$, inciso I, e 485 , inciso IV, do CPC/2015.

\subsubsection{Existência de convenção de arbitragem}

Convenção de arbitragem é negócio jurídico pelo qual as partes envolvidas estabelecem que o litígio (já existente ou futuro e eventual) será solucionado por meio da arbitragem. Em regra, somente é permitida a celebração dessa convenção por pessoas capazes de contratar e em relação a litígios sobre direitos patrimoniais disponíveis (Lei $n^{\circ}$. 9.307/1996) ${ }^{26}$. Por conseguinte, a atuação jurisdicional do Estado fica afastada, no que se refere à atividade certificação de direitos (= processo de conhecimento), porque a prática de medidas constritivas de direitos (cumprimento de sentença ou tutelas provisórias) ainda continuam a exigir intervenção do Judiciário ${ }^{27}$.

${ }^{25}$ SOARES, Carlos Henrique. Curso de Teoria Geral do Processo Civil. Belo Horizonte; Editora D’Plácido, 2019, p. 431-432.

${ }^{26}$ Importante dizer que a Lei $n^{\circ} .13 .129 / 2005$ alterou a Lei $n^{\circ} .9 .307 / 1996$ para instituir que a administração pública direta ou indireta para celebrar convenção de arbitragem, a fim de solucionar litígios relativos a direitos patrimoniais disponíveis.

${ }^{27}$ Sobre o assunto, não se pode ignorar a existência de projetos de lei que visam à desjudicialização da execução no Brasil (PL nº 6.204/2019 e PL n 4.257/2019). Quem tiver interesse, consultar, entre outros: HILL, Flávia Pereira. Desjudicialização da Execução Civil: reflexões sobre o Projeto de Lei n 6.204/2019. Revista eletrônica de direito processual - REDP, v. 21, p. 164-205, 2020; FREITAS, Helena Patrícia. Processo de Execução: da análise econômica do Direito ao debate cerca da desjudicialiizacão. In: ALVES, Lucélia de Sena; SOARES, Carlos Henrique; FARIA, Gustavo de Castro; BORGES, Fernanda Gomes e Souza. (Org.). 4 Anos de vigência do Código de Processo de 2015. Belo Horizonte-MG: Editora D'Plácido, 2020, p. 259-276; ANDRADE, Juliana Melazzi. A delegação do exercício da competência no processo executivo brasileiro. Revista de Processo (RePro), v. 296, Ano 43, out/2019, p. 111-147, 2019; THEODORO JR., Humberto. A desjudicialização da execução civil: projetos legislativos em andamento. Revista de Processo (RePro), v. 313, Ano 45, mar/2021, p. 153-163, 2021. 
De toda sorte, a convenção de arbitragem é preliminar peremptória, pois seu acolhimento, inevitavelmente, acarreta a extinção do processo sem apreciação do mérito. Vale frisar que incumbe ao réu argui-la na contestação, sob a consequência de aceitação da jurisdição estatal e renúncia ao juízo arbitral, uma vez que se não admite ao juiz reconhecê-la ex officio (art. $337 \S \S 6^{\circ}$ e $\left.7^{\circ} \mathrm{CPC} / 2015\right)^{28}$. Portanto, é dever do réu arguir a existência de convenção de arbitragem na forma e prazo da contestação e, ao final, manifestar resistência para que tal preliminar seja acolhida e o processo seja extinto sem apreciação do mérito.

\subsubsection{Ausência de legitimidade ou falta de interesse de processual}

Ausência de legitimidade e falta de interesse processual são duas questões preliminares que foram normatizadas conjuntamente no inciso IX do art. 337 do CPC. As situações fáticas de incidência e as consequências jurídicas de cada uma delas são distintas, de modo que o tratamento conjunto somente pode ser justificado pela circunstância de ambas dizerem respeito às "condições da ação" ou "aos requisitos de admissibilidade do julgamento do mérito" 29.

Interesse processual diz respeito à necessidade e adequação da pretensão deduzida em juízo pelo autor. A necessidade reside na impossibilidade de o autor obter o que pretende (bem jurídico da vida) sem a devida intervenção do Estado. A adequação referese à correspondência e à aptidão do pedido formulado para resolver o litígio narrado na petição inicial. Em resumo, o interesse processual liga às ideias de utilidade e necessidade da atividade jurisdicional para solucionar o litígio ${ }^{30}$.

A ausência de legitimidade diz respeito às circunstâncias que autor e/ou réu não possuírem pertinência subjetiva com o mérito do processo, que é extraível da narrativa da

\footnotetext{
${ }^{28}$ SOARES, Carlos Henrique. Curso de Teoria Geral do Processo Civil. Belo Horizonte; Editora D'Plácido, 2019, p. 432-434.

${ }^{29}$ A expressão é utilizada por Ronaldo Brêtas de Carvalho Dias, com apoio nos estudos de Cândido Rangel Dinamarco e José Roberto dos Santos Bedaque, ao discorrer acerca da polêmica envolvendo a extinção das categorias "condições da ação" e "carência de ação" pelo CPC vigente. A quem possa interessar, consultar: BRÊTAS, Ronaldo de Carvalho Dias. Fundamentos e inovações do Código de Processo Civil. Belo Horizonte, D'Plácido, 2020, p. 129-135.

${ }^{30}$ NEVES, Daniel Amorim Assumpção. Manual de Direito Processual Civil - Volume único. $8^{\mathrm{a}}$ Edição. Salvador: JusPodivm, 2016, p. 74-76.
} 
causa de pedir e dos pedidos formulados. Para que a apreciação do mérito ocorra é necessário sejam legítimos tanto autor quanto o réu.

Se a ilegitimidade for da parte autora, a consequência jurídica é uma só: extinção do processo sem apreciação do mérito. Tanto é que uma das causas de indeferimento da petição inicial é a manifesta ilegitimidade da parte (art. 330, II, CPC).

A situação é diferente quando se está diante de ilegitimidade do réu, porque os artigos 338 e 339 do CPC normatizam a possibilidade de correção da legitimidade passiva. Assim o faz por meio de incidente processual que viabiliza a substituição do réu ilegítimo pela parte legítima, ou até mesmo a inclusão de outro réu, formando-se litisconsórcio ulterior.

Explica-se. Quando o réu arguir sua ilegitimidade para participar do processo ou afirmar não ser responsável pelo prejuízo invocado, deverá indicar quem é a parte legítima, sempre que tiver conhecimento, sob a consequência de ter que arcar com as despesas processuais e indenizar o autor pelos prejuízos decorrentes da falta de indicação exigida. Feito isso, o juiz facultará ao autor emendar a petição inicial para substituição do réu ou para inclusão da pessoa indicada como parte legítima pelo réu, formando-se litisconsórcio, assinando-lhe prazo de 15 dias para qualquer das opções.

Nessa perspectiva, quando o réu arguir sua ilegitimidade deverá indicar, quando tiver condições, quem é a parte legítima e manifestar resistência no sentido de que se proceda à correção da legitimidade passiva do processo, mediante sua substituição pela parte indicada como legítima.

Por outro lado, se o réu arguir ilegitimidade por parte do autor, deverá pleitear a extinção do processo sem apreciação do mérito (artigos 330, II, e 485, IV, CPC). Idêntica situação deverá ocorrer quando se estiver diante da ausência de interesse processual.

De toda sorte, é preciso ter maior atenção em relação a essas questões preliminares, em razão do fato de que o Superior Tribunal de Justiça vem consolidando jurisprudência no sentido de adoção da "teoria da asserção" ${ }^{31}$. Segundo tal concepção

\footnotetext{
${ }^{31}$ BRASIL, Superior Tribunal de Justiça. Resp no 832.370/MG, Relatora Ministra Nancy Andrighi, $3^{\mathrm{a}}$ Turma. Diário de Justiça: Brasília, 13 ago. 2007; BRASIL, Superior Tribunal de Justiça. Resp no 879188/RS, Relator Humberto Martins, 2a Turma. Diário de Justiça: Brasília, 02 jun. 2009; BRASIL, Superior Tribunal de Justiça. Resp $n^{\circ}$ 1.072814/RS, Relator Massami Uyeda, $2^{a}$ Turma. Diário de Justiça: Brasília, 02 out. 2008.
} 
teórica, o juiz deveria verificar se as "condições da ação" ou os "requisitos de admissibilidade do mérito" estão presentes ao despachar a petição inicial, analisando apenas afirmações feitas pelo autor, independentemente de sua comprovação no processo. Logo, se ausente legitimidade ou interesse processual, o processo seria extinto sem resolução do mérito. Porém, se a constatação da ausência de legitimidade ou do interesse processual ocorrer em momento procedimental posterior, mediante cognição profunda e após esgotados os meios probatórios, o juiz deveria proferir sentença de mérito, julgandose improcedente o pedido do autor ${ }^{32}$.

Por conseguinte, é recomendável que o réu dê ênfase à arguição das preliminares de "ausência de legitimidade ou interesse processual" (art. 337, XI, CPC), quando tal for cabível. Isso pela circunstância de que sua arguição na contestação gera controvérsia e fomenta discussão sobre as "condições da ação", uma vez que o autor se manifestará a respeito na réplica (art. $351 \mathrm{CPC)}$ e o juiz deverá pronunciar sobre essas questões processuais dependentes na decisão de saneamento e organização do processo (art. 357 CPC). Aprofundar as discussões e a cognição judicial acerca da ausência de legitimidade ou de interesse processual potencializa, pois, o proferimento de sentença de mérito, mediante maior aproveitamento processual, o que pode ser de interesse do réu.

\subsubsection{Falta de caução ou outra prestação que a lei exige como preliminar}

Em situações específicas, a legislação dispõe ser necessário o oferecimento de caução ou outra prestação preliminar para viabilizar o regular desenvolvimento do processo, com vistas à apreciação do mérito - pressuposto processual. Os exemplos mais nítidos são referentes às situações: 1) em que o autor residir ou passar a residir fora do (e não possuir bens imóveis no) Brasil $^{33}$ (art. $83 \mathrm{CPC}$ ); 2) de deposito inicial na ação rescisória, referente à 5\% sobre o valor da causa (art. 968, inciso II, CPC).

\footnotetext{
${ }^{32}$ BAHIA, Alexandre; NUNES, Dierle; QUINAUD PEDRON, Flávio. Teoria Geral do Processo: com comentários sobre a virada tecnológica no direito processual. Salvador: JusPodivm. 2020, p. 226-232; NEVES, Daniel Amorim Assumpção. Manual de Direito Processual Civil - Volume único. $8^{a}$ Edição. Salvador: JusPodivm, 2016, p. 69-70.

${ }^{33}$ SCARPINELlA BUENO, Cassio. Manual de Direito Processual Civil: volume único. $4^{a}$ Edição. São Paulo: Saraiva. 2018, p. 372.
} 
Qualquer que seja a situação, será facultado ao autor sanear o vício processual. Somente será o caso de extinção do procedimento sem apreciação do mérito, se o autor não cumprir a diligência necessária ao saneamento do vício processual ${ }^{34}$.

Portanto, quando o réu arguir falta de caução ou outra prestação que a lei exigir como preliminar para o regular desenvolvimento do processo, deverá manifestar resistência no sentido de que seja o autor intimado a prestar a caução ou cumprir outra exigência legal, sob a consequência de extinção do processo sem apreciação do mérito (art. 485, IV, CPC).

\subsubsection{Indevida concessão da gratuidade de justiça}

O deferimento de gratuidade de justiça ao autor pode ser impugnado pelo réu em preliminar de contestação (art. 100 CPC). Trata-se de mais uma novidade, pois antes do início da vigência do atual CPC tal questão era impugnada por exceção, cujo tramite ocorria em autos apartados, nos termos do artigo $7^{\circ}$ Lei $^{\circ} .1 .060 / 1950^{35}$, que foi revogado (art. 1.072, III, CPC).

A finalidade prática em arguir, em contestação, a indevida da gratuidade de justiça deferida ao autor é fazer com que o juiz acolha tal preliminar e determine que o recolhimento das custas processuais iniciais, sob a consequência de extinção do processo sem apreciação do mérito (art. 485, IV, CPC). A indevida concessão de gratuidade de justiça é preliminar dilatória, mas que pode ser tornar peremptória, se a diligência necessária ao saneamento do processual não for cumprida a tempo e modo.

\section{DEFESAS DE MÉRITO}

O conteúdo normativo do caput do art. 337 do CPC dispõe ser incumbência do réu, após eventuais arguições de questões preliminares, defender-se contra o mérito do

\footnotetext{
${ }^{34}$ SOARES, Carlos Henrique. Curso de Teoria Geral do Processo Civil. Belo Horizonte; Editora D'Plácido, 2019, p. 436.

${ }^{35}$ TARTUCE, Fernanda; DELLORE, Luiz Guilherme Pennacchi. Gratuidade da justiça no novo CPC. Revista de Processo, v. 236, p. 305-322, 2014.
} 
processo. Significa dizer que a resistência do réu deve ter como alvo o conteúdo da pretensão do autor, o bem da vida por judicialmente pretendido e identificado no objeto mediato do pedido formulado na petição inicial. A defesa de mérito tem como objetivo gerar controvérsia acerca dos fatos e fundamentos jurídicos, bem como sobre os elementos de provas que embasam os pedidos do autor ${ }^{36}$.

Em relação ao mérito, a defesa no processo civil é dividida em direta e indireta. A direta consiste em negar a ocorrência dos fatos constitutivos do direito do autor (= causa de pedir remota), o que pode ser feito pela afirmativa que não há provas a respeito; e/ou sustentar que as consequências jurídicas indicadas no pedido (= causa de pedir próxima) não encontram respaldo no ordenamento jurídico vigente. Não é por acaso que Daniel Amorim Assumpção Neves afirma que: "a defesa de mérito direta desenvolve-se dentro dos fatos e da fundamentação jurídica que compõe a causa de pedir exposta pelo autor em sua petição inicial"37.

Não custa recordar, conforme exposto nas linhas acimas, que o oferecimento de contestação é orientado pela regra de impugnação específica dos fatos (art. 341 CPC), impondo ao réu se opor aos fatos referentes à constituição do direito de autor de forma ordenada e especificada. Em regra, é vedado contestar mediante negativa genérica. Não menos importante é o destaque de que a apresentação de defesa direta traz consigo a consequência de impedir que os fatos afirmados na petição inicial sejam presumidos como verdadeiros, de modo a manter como o autor ônus de comprovar a sua ocorrência (art. 373, I, CPC).

\subsection{Defesa direta}

\footnotetext{
${ }^{3636}$ NEVES, Daniel Amorim Assumpção. Manual de Direito Processual Civil - Volume único. $8^{\text {a }}$ Edição. Salvador: JusPodivm, 2016, p. 592; LEAL, Rosemiro Pereira. Teoria geral do processo: primeiros estudos. $8^{\text {a }}$. Ed. Belo Horizonte: Forense, 2009, p. 135-136; 308-308; SOARES, Carlos Henrique. Curso de Teoria Geral do Processo Civil. Belo Horizonte; Editora D’Plácido, 2019, p. 200-201; DINAMARCO, Cândido Rangel. O conceito de mérito no processo civil. Revista de Processo (RePro), Vol. 34. São Paulo: Editora Revista dos Tribunais, p. 20-46, abr./jun, 1984.

${ }^{37}$ NEVES, Daniel Amorim Assumpção. Manual de Direito Processual Civil - Volume único. $8^{a}$ Edição. Salvador: JusPodivm, 2016, p. 592.
} 
Exemplos, ainda que sejam simples, ajudam na compreensão do exposto, razão pela qual serão abaixo apresentados dois.

Exemplo 1: "ação de cobrança". Imagine que João tenha instaurado procedimento para cobrar de José o cumprimento de obrigação consistente no pagamento da quantia de $\mathrm{R} \$ 50.000,00$, decorrente de contrato de mútuo (= empréstimo de coisa fungível) firmado pelas partes. Nesse hipotético caso, o réu pode apresentar defesa direta, negando que o fato constitutivo do direito do autor tenha ocorrido. É oportuno salientar que fato constitutivo de direito consiste na narrativa na qual se funda a pretensão ${ }^{38}$ deduzida em juízo pelo autor. Logo, fato constitutivo do direito do autor numa ação de cobrança é a existência do referido contrato.

Exemplo 2: Maria ajuíza ação de reconhecimento e dissolução de união estável em desfavor de Mário, pedindo também sejam partilhados os bens adquiridos pelo casal durante a constância da convivência conjugal. Suponha que a autora afirme na petição inicial que manteve com o réu relacionamento afetivo por cerca de 7 anos - entre fevereiro de 2011 até janeiro de 2018, período em que coabitaram numa casa na capital mineira; frequentavam eventos sociais e festivos; foram padrinhos de casamentos de vários casais do grupo de amigos que tinham em comum. Também afirme que o réu adquiriu um lote não edificado ( $\mathrm{R} \$ 70.000,00)$ e um veículo $(\mathrm{R} \$ 28.000,00)$. Vê-se que, nesse caso, os fatos constitutivos do direito da autora decorrem dos pressupostos de configuração da união estável [= convivência pública, contínua e duradoura, com a intenção de constituir família (art. 1.723 CC/02)], bem como da norma do artigo 1.725, também do CC/02, ao estabelecer que na união estável, salvo contrato escrito entre os companheiros, aplica-se às relações patrimoniais, no que couber, o regime da comunhão parcial de bens (artigos

\section{$1.658 / 1.666 \mathrm{CC} / 02)$.}

$\mathrm{Na}$ ação de reconhecimento e dissolução de união estável com partilha de bens, o réu pode, por hipótese, apresentar defesa direta, sob o argumento de que: ( $a$ ) não tenha se

\footnotetext{
${ }^{38}$ No texto, pretensão tem sentido de declaração de vontade (ato jurídico) pela qual é formulada determinada exigência a ser cumprida por outrem. É apenas o que o autor aspira conseguir com o processo, podendo, assim, ser julgada procedente ou improcedente. Mais sobre este interesse tema, conferir: (BRÊTAS, Ronaldo de Carvalho Dias. Processo Constitucional e Estado Democrático de Direito. $4^{\text {a }}$ Edição. Belo Horizonte: Editora Del Rey. 2018, p. 93-103; FIUZA, César Augusto de Castro; RIBEIRO, Regina. A prescrição em face da autonomia do direito de agir: abordagem histórico-dogmática. Revista Campo Jurídico, v. 1, p. 215-234, 2013).
} 
relacionado com a autora; (b) tal relação não foi pública, contínua e duradoura; $(c)$ principalmente, não havia intenção de constituição de família; $(d)$ não tenha adquirido referidos bens durante a vigência da suposta união.

Nos exemplos de defesa direta apresentados, cumpre anotar que o réu deverá manifestar, ao final de sua contestação, resistência no sentido de que o juiz julgue improcedente os pedidos iniciais. Assim o deverá fazer sob o fundamento que os fatos constitutivos do direito do autor não ocorreram e/ou que as consequências jurídicas descritas nos pedidos iniciais não encontram respaldo normativo no ordenamento jurídico, ou não foram comprovados em juízo, ou seja, a pretensão deduzida pelo autor é infundada.

\subsection{Defesa indireta}

O réu também pode apresentar defesa indireta, que se caracteriza pela aceitação de que os fatos articulados pelo autor como constitutivos de seu direito tenham ocorridos e que as consequências jurídicas descritas no pedido encontram respaldo na ordem jurídica. Porém, são lhes opostos fatos impeditivos, modificativos ou extintivos. Isto é, a defesa indireta não é negativa, mas aditivas, porque por ela o réu acresce ao mérito novas questões fático-jurídicas, formatando, por completo, o objeto do processo ${ }^{39}$.

Explica-se, fazendo-se recursos aos exemplos apresentados anteriormente.

Primeiro, o fato extintivo é aquele que põe fim à pretensão jurídica deduzida no processo pelo autor. No caso da ação de cobrança, o pagamento da dívida decorrente do contrato de mútuo e a prescrição da pretensão de exigir o cumprimento da obrigação são fatos extintivos do direito do autor, haja vista que extingue a obrigação (no caso do pagamento) ou a responsabilidade do mutuante (no caso da prescrição ${ }^{40}$ ).

Segundo, o fato impeditivo tem conteúdo negativo e é marcado pela ausência de algum dos requisitos genéricos de validade do ato, fato ou negócio jurídico referente à

\footnotetext{
${ }^{39}$ Interesse discussão sobre o que constitui objeto do processo e sua relação com o mérito, consultar: DINAMARCO, Cândido Rangel. O conceito de mérito no processo civil. Revista de Processo (RePro), Vol. 34. São Paulo: Editora Revista dos Tribunais, p. 20-46, abr./jun, 1984.

${ }^{40}$ FIUZA, César Augusto de Castro; RIBEIRO, Regina. A prescrição em face da autonomia do direito de agir: abordagem histórico-dogmática. Revista Campo Jurídico, v. 1, p. 215-234, 2013.
} 
pretensão deduzida em juízo pelo autor. A ausência de qualquer desses requisitos impede a formação válida do ato, fato ou negócio jurídica que diz respeito à pretensão autoral e, via de consequência, à constituição do direito do autor. No exemplo 1, é fato impeditivo do direito do autor toda e qualquer circunstância referente às causas de invalidade do contrato de mútuo. No caso da união estável, podem ser mencionadas às causas de impedido de casamento (art. $1.723, \S 1^{\circ}$, e $1.521 \mathrm{CC} / 02$ ); ou, especificamente em relação à partilha dos bens, as situações de exclusão da comunhão (art. $1.569 \mathrm{CC} / 02$ ).

Terceiro, o fato modificativo é caracterizado por alterar o conteúdo da pretensão deduzida em juízo. No exemplo 1, seriam as hipóteses de o réu afirmar que cumpriu parcialmente a obrigação, que pagou 30\% do cobrado; e/ou que o autor teria uma dívida com o réu no valor de $\mathrm{R} \$ 10.000,00$, o que lhe confere o direito de compensar o débito. No exemplo 2, o réu pode argumentar que a relação afetiva, pública, duradoura, contínua e com intenção de constituir família durou bem menos que sete anos; que parcela dos bens adquiridos na constância da união foram adquiridos em substituição a outros que o réu já possuía antes da união.

Do ponto de vista da técnica processual, é pertinente anotar que para as defesas indiretas, que se referem a fatos extintivos ou impeditivos do direito do autor, o réu deverá manifestar resistência no sentido de que sejam julgados improcedentes os pedidos do autor. Lado outro, no que diz respeito às defesas indiretas, pertinentes a fatos modificativos do direito do autor, a resistência será no sentido de que sejam julgados parcialmente procedentes os pedidos do autor.

\section{RESISTÊNCIA E PROVOCAÇÃO DO JUÍZO}

Ao final da contestação é preciso concluir o ato de defesa, ou seja, manifestar formalmente resistência, provocando, de maneira inequívoca, o juízo a apreciar as questões ali arguidas, com a indicação da consequência lógico-jurídica disposta no ordenamento jurídico.

\subsection{Conclusão da defesa: manifestação de resistência do réu}


Recorda-se que contestação é a forma jurídico-processual pela qual o réu manifesta sua resistência, opondo-se ao procedimento instaurado e/ou à pretensão do autor. O réu, após arguir preliminares e/ou apresentar defesa de mérito, precisa provocar o juiz a apreciar as questões ali suscitadas. Isto se faz, do ponto de vista técnico, mediante a manifestação formal e inequívoca de resistência. Não são, porém, pedidos que veiculam pretensão, como é feito pelo autor na petição inicial. Não se pede para julgar procedente os pedidos iniciais, nem para condenar ao cumprimento de alguma obrigação ou declarar a existência de algum fato, por exemplo. São manifestações pertinentes à defesa apresentada, as quais expressam resistência, oposição ao procedimento e/ou ao mérito da causa $^{41}$.

Na contestação, as manifestações de resistência hão de observar a classificação da defesa apresentada: defesas preliminares dilatórias, peremptórias ou dilatórias potencialmente peremptórias; defesas de mérito direta ou indireta. É imperioso provocar o juiz a acolher a questão preliminar ou mérito arguida e, via de consequência, aplicar a consequência jurídica decorrente de seu acolhimento, indicando-a (extinção do processo sem apreciação do mérito, julgamento de improcedência dos pedidos iniciais, conforme o caso).

Por apego à didática, apresenta-se quadro esquemático com resumo das relações existentes entre a matéria de defesa arguida, as consequências jurídicas do acolhimento da questão suscitada e sugestões de redação manifestações de resistência que podem ser formuladas na contestação.

\begin{tabular}{|l|l|l|}
\hline Matéria de defesa & $\begin{array}{l}\text { Consequência jurídica do } \\
\text { seu acolhimento }\end{array}$ & $\begin{array}{l}\text { Sugestões de redação de } \\
\text { manifestação } \\
\text { resistência }\end{array}$ \\
\hline Preliminar Peremptória & $\begin{array}{l}\text { Extinção do procedimento } \\
\text { sem apreciação do mérito. }\end{array}$ & $\begin{array}{l}\text { Pede-se } \text { a Vossa } \\
\text { Excelência que acolha a(s) } \\
\text { preliminar }(\text { es }) \quad \text { - } \\
\text { litispendência, coisa } \\
\text { julgada ou convenção de } \\
\text { arbitragem, por exemplo-, }\end{array}$ \\
\hline
\end{tabular}

\footnotetext{
${ }^{41}$ Beclaute Oliveira Silva defende que o réu formula pedido na contestação. A respeito, consultar: SILVA, Beclaute Oliveira. O autor pede... O réu também! Ou da improcedência como procedência. Revista ANNEP de Direito Processual. Vol. 1. No 1, jan/jun, 2020, p. 82-90.
} 
Rio de Janeiro. Ano 16. Volume 23. Número 1. Janeiro a Abril de 2022

Periódico Quadrimestral da Pós-Graduação Stricto Sensu em Direito Processual da UERJ

Patrono: José Carlos Barbosa Moreira (in mem.). ISSN 1982-7636. pp. 547-577

www.redp.uerj.br

\begin{tabular}{|c|c|c|}
\hline & & $\begin{array}{lr}\text { para extinguir } & o \\
\text { procedimento } & \text { sem } \\
\text { resolução do mérito. } & \end{array}$ \\
\hline Preliminar dilatória & 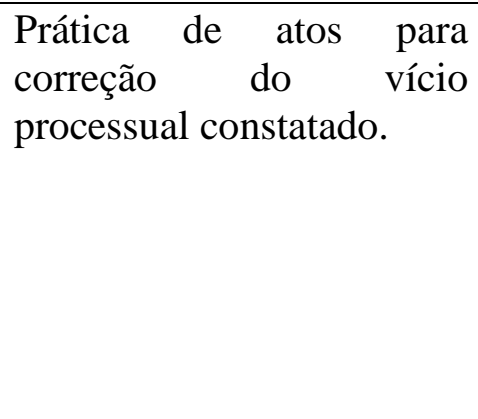 & $\begin{array}{l}\text { (1) Pede-se a Vossa } \\
\text { Excelência que acolha a } \\
\text { preliminar } \\
\text { incompetência do juízo, } \\
\text { por exemplo), } \\
\text { determinando-se a remessa } \\
\text { dos autos ao juízo } \\
\text { competente. }\end{array}$ \\
\hline $\begin{array}{l}\text { Preliminar dilatória } \\
\text { potencialmente } \\
\text { peremptória }\end{array}$ & $\begin{array}{l}\text { Determinação de diligência } \\
\text { para correção do vício } \\
\text { processual, sob a sanção de } \\
\text { proferimento de sentença } \\
\text { terminativa. }\end{array}$ & $\begin{array}{l}\text { Pede-se a Vossa } \\
\text { Excelência que acolha a } \\
\text { preliminararguida (defeito } \\
\text { de representação, por } \\
\text { exemplo) e determine que o } \\
\text { autor regularize sua } \\
\text { representação processual, } \\
\text { sob a consequência de } \\
\text { extinção do processo sem } \\
\text { resolução do mérito. }\end{array}$ \\
\hline Defesa de mérito direta & $\begin{array}{l}\text { Julgamento de } \\
\text { improcedência dos pedidos } \\
\text { iniciais. }\end{array}$ & $\begin{array}{l}\text { Pede-se a Vossa } \\
\text { Excelência que se digne a } \\
\text { julgar improcedentes os } \\
\text { pedidos iniciais, ante a } \\
\text { ausência de provas elou de } \\
\text { amparo legal. }\end{array}$ \\
\hline Defesa de mérito indireta & $\begin{array}{l}\text { (1) Se pertinente a fato } \\
\text { extintivo e/ou impeditivo } \\
\text { de direito do autor, } \\
\text { julgamento } \\
\text { improcedência dos } \\
\text { pedidos iniciais: } \\
\text { (2) Se pertinente a fato } \\
\text { modificativo de direito do } \\
\text { autor, julgamento de } \\
\text { parcial procedência dos } \\
\text { pedidos iniciais. }\end{array}$ & 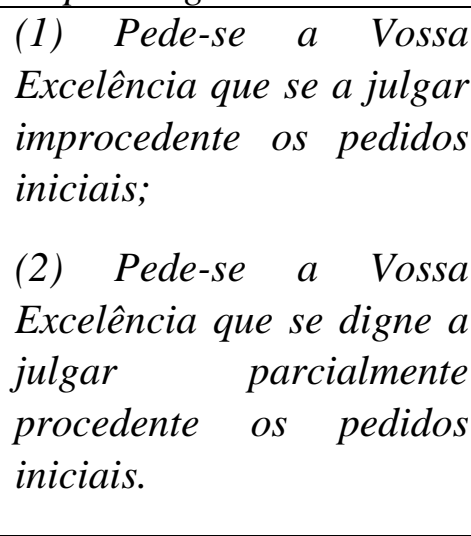 \\
\hline
\end{tabular}

\subsection{Requerimentos}


Além de manifestar resistência, o réu pode apresentar requerimentos, provocando que juízo determine a prática de algum ato processual necessário ou pertinente, a exemplo da citação do denunciado à lide ou do chamado ao processo, quando for o caso.

Deve também especificar as provas que almeja produzir (art. $336 \mathrm{CPC}$ ), por intermédio de requerimento de meios com os quais pretende fixar ou demonstrar os fatos articulados na sua defesa ${ }^{42}$, especialmente os modificativos, extintivos ou impeditivos do direito do autor (art. 373, II, CPC).

A propósito, cabe anotar ser comum a formulação de requerimento de prova muito genérico, como por exemplo: “a parte ré protesta por produzir provas por todos os meios admitidos em direito", o que não é tecnicamente correto, a rigor. A imprecisão técnica decorre pela circunstância de não ser admissível produz provas por outros meios senão aqueles permitidos pela ordem jurídica. Ademais, mostra-se importante que o requerimento de provas não seja compreendido como simples requisito da petição inicial ou mera formalidade da contestação, os quais, inclusive, seriam convalidáveis, haja vista da consagrada prática de intimação das partes para especificação das provas. É interessante perceber que há correlação entre as narrativas fático-jurídicas articuladas pelas partes (causa de pedir, pelo autor; e matéria de defesa pelo réu) e a prova a ser produzida. Cada parte, pois, deverá, de acordo com o seu ônus probatório ${ }^{43}$ (art. 373 CPC), formular requerimento específico de prova pelos meios técnicos estabelecidos em lei: oral, documental e pericial.

\footnotetext{
${ }^{42}$ Assim o é porque, consoante destaca Ronaldo Brêtas, o procedimento probatório é estruturado técnica e normativamente por quatro fases ou etapas lógicas: $1^{\mathrm{a}}$ ) proposição ou indicação; $2^{\mathrm{a}}$ ) admissão; $3^{\mathrm{a}}$ ) produção ou concretização; $4^{a}$ ) valoração. A primeira fase ou etapa é justamente aquela em que autor, na petição inicial (art. 319, VI, CPC), e réu, na contestação (art. 336 CPC), formulam requerimento de provas. Na segunda fase ou etapa consiste nos pronunciamentos decisórios pelos quais o juiz aprecia os requerimentos de provas formulados pelas partes. A decisão de saneamento e organização do processo - art. 357 CPC pode ser indicada como o principal ato de admissão da prova. Na terceira fase ou etapa, os elementos de provas são colhidos e transportados à estrutural procedimental regida pelas garantias processuais, a partir dos meios técnicos previamente normatizados. Na quarta e última etapa ou fase, os elementos de provas trazidos aos autos do procedimento são valorados pelas partes, mediante a indicação de sua existência e estabelecimento de liame argumentativo de pertinência entre os fatos e as questões discutidas no processo (BRÊTAS, Ronaldo de Carvalho Dias. Noções de teoria e técnica do procedimento da prova. In: BRÊTAS, Ronaldo de Carvalho Dias; SOARES, Carlos Henrique (org.) Técnica Processual. Belo Horizonte: Del Rey, 2015, p. 191-192).

${ }^{43}$ Interesse e profunda discussão sobre ônus da probatório no marco do modelo constitucional do processo, ver: PAOLINELLI, Camilla Mattos. O ônus da prova no processo democrático. Rio de Janeiro: Lumen Juris, 2014.
} 
Mais que isso. É preciso iniciar, desde logo, a preparação do processo, traçando estratégias probatórias, em consonância à ordem jurídica e à melhor técnica processual. Se os fatos de defesa do réu são passíveis de provas documentais, estas devem ser anexadas à contestação; se estão na posse do autor ou terceiro, necessário requer sejam exibidas em juízo. Lado outro, se os fatos forem necessitarem de provas por meio oral ou pericial, é oportuno informar o cliente sobre os custos para produção desta e daquela prova e discutir a melhor estratégia para obtenção de êxito.

Feito isso e para ser mais objetivo, é imprescindível recordar que o réu tem ônus de provar os fatos impeditivos, modificativos e extintivos do direito do autor, de sorte a ser essa orientação para formulação de seu requerimento de provas. Sugestão: "o réu protesta por provas os fatos extintivos, modificativos ou impeditivos do direito do autor por meio documental, oral e pericial".

\section{CONSIDERAÇÕES FINAIS}

A título de conclusão, articula-se as seguintes assertivas:

1. Elaborar contestação é ato complexo e eminentemente técnico, a exigir do advogado, público ou privado, muita atenção e amplo conhecimento não só sobre processo civil, mas também a respeito da questão de direito material que fundamenta a pretensão deduzida em juízo.

2. A defesa eficaz reclama abrangência, precisão e técnica. Abrangência em relação ao seu conteúdo, o que se faz mediante a suscitação de questões preliminares e de mérito, direta e indireta. Precisão em relação aos fatos constitutivos do direito do autor e aos documentos anexados à petição inicial, impugnando-os especificadamente - "um por um" -, de sorte gerar controvérsia e dúvida a respeito de suas respectivas pertinente e validade jurídicas. E técnica processual acerca dos pedidos e requerimentos formulados, além da estratégia probatória que se inicia para o réu na contestação. 


\section{REFERÊNCIAS:}

ANDRADE, Juliana Melazzi. A delegação do exercício da competência no processo executivo brasileiro. Revista de Processo (RePro), v. 296, Ano 43, out/2019, p. 111147, 2019.

BAHIA, Alexandre; NUNES, Dierle; QUINAUD PEDRON, Flávio. Teoria Geral do Processo: com comentários sobre a virada tecnológica no direito processual. Salvador: JusPodivm. 2020.

BARACHO, José Alfredo de Oliveira Teoria geral do processo constitucional. Revista da Faculdade Mineira de Direito, Belo Horizonte, v. 2, n. 3 e 4, p. 89-154, $1^{\circ}$ e $2^{\circ}$ sem. 1999.

BARACHO, José Alfredo de Oliveira. Direito processual constitucional: aspectos contemporâneos. Belo Horizonte: Fórum, 2008.

BARROS, Flaviane de Magalhães; CARVALHO, Marius Fernando Cunha de; GUIMARÃES, Natália Chernicharo. O consenso compreendido a partir do paradigma do Estado Democrático de Direito. Revista de Informação Legislativa, Brasília, v. 168, nº dez, 2005, p. 147-153.

BRASIL, Superior Tribunal de Justiça. Resp nº 832.370/MG, Relatora Ministra Nancy Andrighi, $3^{\text {a }}$ Turma. Diário de Justiça: Brasília, 13 ago. 2007.

BRASIL, Superior Tribunal de Justiça. Resp nº 1.072814/RS, Relator Massami Uyeda, $2^{\text {a }}$ Turma. Diário de Justiça: Brasília, 02 out. 2008.

BRASIL, Superior Tribunal de Justiça. Resp no 879188/RS, Relator Humberto Martins, $2^{\text {a }}$ Turma. Diário de Justiça: Brasília, 02 jun. 2009.

BRÊTAS, Ronaldo de Carvalho Dias. Processo Constitucional e Estado Democrático de Direito. $4^{\mathrm{a}}$ Edição. Belo Horizonte: Editora Del Rey. 2018.

BRÊTAS, Ronaldo de Carvalho Dias. Fundamentos e inovações do Código de Processo Civil. Belo Horizonte, D’Plácido, 2020.

COSTA, Eduardo José da Fonseca. Presunção de inocência civil: algumas reflexões no contexto brasileiro. Revista Brasileira de Direito Processual - RBDPro, Belo Horizonte, ano 25, n. 100, p. 129-144, out./dez. 2017. 
DIDIER JR., Fredie. Curso de Direito Processual Civil: introdução ao direito processual civil parte geral e processo de conhecimento. Vol. 1. 17 Edição. Salvador: Editora JusPodivm, 2015.

DINAMARCO, Cândido Rangel. O conceito de mérito no processo civil. Revista de Processo (RePro), Vol. 34. São Paulo: Editora Revista dos Tribunais, p. 20-46, abr./jun, 1984.

FIUZA, César Augusto de Castro; RIBEIRO, Regina. A prescrição em face da autonomia do direito de agir: abordagem histórico-dogmática. Revista Campo Jurídico, v. 1, p. 215-234, 2013.

FREITAS, Helena Patrícia. Processo de Execução: da análise econômica do Direito ao debate cerca da desjudicialiizacão. In: ALVES, Lucélia de Sena; SOARES, Carlos Henrique; FARIA, Gustavo de Castro; BORGES, Fernanda Gomes e Souza. (Org.). 4 Anos de vigência do Código de Processo de 2015. Belo Horizonte-MG: Editora D'Plácido, 2020, p. 259-276.

HILL, Flávia Pereira. Desjudicialização da Execução Civil: reflexões sobre o Projeto de Lei $\mathrm{n}^{\circ}$ 6.204/2019. Revista eletrônica de direito processual-REDP, v. 21, p. 164205, 2020.

LEAL, Rosemiro Pereira. Teoria geral do processo: primeiros estudos. $8^{\mathrm{a}}$. Ed. Belo Horizonte: Forense, 2009.

NEVES, Daniel Amorim Assumpção. Manual de Direito Processual Civil - Volume

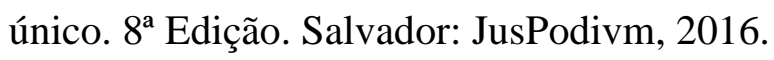

PAOLINELLI, Camilla Mattos. O ônus da prova no processo democrático. Rio de Janeiro: Lumen Juris, 2014.

PINHEIRO, Guilherme César. O Novo Código de Processo Civil e as alterações não explícitas sobre a petição inicial. Revista de Processo. Vol. 258. Ano 41. São Paulo: Editora Revista dos Tribunais, p. 85-102, ago. 2016.

PINHEIRO, Guilherme César; SOUSA, Lorena Ribeiro de Carvalho. A petição inicial e os seus requisitos no Novo Código de Processo Civil. REVISTA ESMAT, v. 10, n. 15, 30, p. 75-104, ago. 2018. 
PINHEIRO, Guilherme César. A audiência de conciliação e mediação no sistema processual civil. Revista Eletrônica de Direito Processual - REDP. Rio de Janeiro. Ano 12. Volume 19. Número 3, p. 324-347, setembro a dezembro de 2018.

RODRIGUES JR., Walsir Edson. O sistema dual facultativo de dissolução do casamento no projeto do novo Código de Processo Civil. In: FREIRE, Alexandre; DANTAS Bruno; NUNES, Dierle; DIDIER JR., Fredie; MEDINA, José Miguel Garcia; FUX Luiz; VOLPE CAMARGO, Luiz Henrique; OLIVEIRA, Pedro Miranda de. (Org.). Novas Tendências do Processo Civil. Salvador: JusPODIVM, 2014, v. 3, p. 791806.

SCARPINELLA BUENO, Cassio. Manual de Direito Processual Civil: volume único. $4^{\mathrm{a}}$ Edição. São Paulo: Saraiva. 2018.

SILVA, Beclaute Oliveira. O autor pede... O réu também! Ou da improcedência como procedência. Revista ANNEP de Direito Processual. Vol. 1. № 1, jan/jun, 2020, p. 82-90.

SOARES, Carlos Henrique. Curso de Teoria Geral do Processo Civil. Belo Horizonte; Editora D’Plácido, 2019.

TARTUCE, Fernanda; DELLORE, Luiz Guilherme Pennacchi. Gratuidade da justiça no novo CPC. Revista de Processo, v. 236, p. 305-322, 2014.

THEODORO JR., Humberto. Curso de Direito Processual Civil - Volume I. 56a Edição. Rio de Janeiro: Forense. 2015.

THEODORO JR., Humberto. A desjudicialização da execução civil: projetos legislativos em andamento. Revista de Processo (RePro), v. 313, Ano 45, mar/2021, p. 153163, 2021. 